\title{
The Role of General Election Commission (KPU) in Increasing Voters' Participation in Langkat, Medan, Indonesia
}

\author{
Dedi Amrizal ${ }^{1}$, Yusriati ${ }^{1}$, Hermansyah Lubis ${ }^{1}$ \\ ${ }^{1}$ Muhammadiyah University of North Sumatera(UMSU), Medan, Indonesia \\ dediamrizal@umsu.ac.id
}

\begin{abstract}
Voter participation in elections is one of the benchmarks of the success of political development. The high level of voter participation will indicate the success of the elections and the low voter participation will indicate the failure of the election. Therefore, it is necessary to increase the participation of the voters as the responsibility of the KPU. Therefore, the KPU makes an effort to increase voter participation by conducting election socialization in Langkat Regency. The socialization aims to provide and disseminate information on elections. The effort is certainly to increase voter participation in the election. From this research is done with the aim to know the role of Election Commission Langkat in order to increase voter participation. The method used in this research is descriptive research method with qualitative approach. Analysis of the whole data is done with summarize data that is selecting data, simplified, and taken the main meaning (essence). Based on measurement of effectiveness of election socialization such as; achievement of objectives, procedures, resources, budgets, facilities, infrastructure and integration or cooperation with other organizations. Generated that socialization of election conducted by Langkat Regency KPU not yet effective where achievement of objective, procedure, budget, infrastructure and integration not effective and utilization of resources and facilities running effectively. So the result of this research is the role of Election Commission Langkat in order to increase the voters have not been maximized. With low voter participation rate around $60 \%$ obtained by data processing KPU Langkat Regency.
\end{abstract}

Keywords: general election; voters; participation; society 


\section{INTRODUCTION}

Implementation of General Election as stipulated in Law Number 12 Year 2003 which was then revised in Law Number 22 Year 2007 on the Implementation of General Election states that the General Election (Election) directly by the people is a means of realizing the people sovereignty to produce a democratic state government based on Pancasila and Constitution -The Basic State of the Republic of Indonesia Year 1945.The level of public participation in the general election becomes a measure of the success of the election. The low level of participation in community elections according to Arianto (2011: 59) is caused by several factors that can be classified namely; internal and external factors. Internal factors are technical factors and work factors, while external factors are administrative, socialization and political factors. So the lack of public participation lately has become an important problem to look for solution. Without exception Langkat District is also experiencing the same problem that is decreasing the level of voter participation. Percentage of Community Participation of Langkat Regency is about 60\% $66 \%$. The figure is said to be low because it has not reached the target set by the KPU RI which has a national standard target of voter participation reaching 77.5\%. (Source: Kompas.com Year 2017). In Indonesia the issue of anti-participation in the sense of not participating in the election is referred to as the white group (Golput), a group that consciously declares itself not to vote. The reason given by the voter golput also vary, ranging from busy, no time, do not believe in the candidate, no benefit to them, waste of money alone and others. Electoral participation is a public awareness to participate in the electoral process. The lack of participation is also a lack of political awareness of the people in democracy through elections. Participation can be enhanced through awareness, coaching and education of the community. Formation of awareness, coaching and political education can be done with election socialization program. The socialization of the election has become the responsibility of the KPU in accordance with the explanation in the Regulation of the General Election Commission Number 5 of 2015 concerning Socialization and 
Public Participation in the Election of Governor and Deputy Governor, Regent and Deputy Regent and / or Mayor and Deputy Mayor. In article 1 point 10 explains that the Socialization of the Implementation of Elections, hereinafter referred to as Socialization of Elections. Socialization Elections is the process of delivering information about the stages and programs of the election The purpose of the socialization by KPU has been stipulated in the Regulation of KPU Number 5 Year 2015 article 3, namely: a) disseminating information on the stages, schedules and election program; b) enhancing community knowledge, understanding and awareness of the rights and obligations in elections; and c) increasing voter participation in elections. Election Commission Langkat, according to Agus Arifin chairman KPUD Langkat said earlier had conducted socialization in several ways either directly (face to face) by inviting community leaders to attend the socialization event conducted by KPUD in KPUD Langkat office, or indirectly by using some media such as using electronic media such as radio, and print media through newspapers, posters, pamphlets, brochures, banners and billboards. The socialization has not been effective, one of them is the implementation of socialization directly (face-to-face) which is only done by inviting community leaders to attend the socialization event held at the Langkat District KPUD office. Not in accordance with Regulation of the General Election Commission Number 5 Year 2015 on Socialization and Public Participation in the Election of Governor and Deputy Governor, Regent and Deputy Regent and / or Mayor and Deputy Mayor. Article 10 describes face-to-face socialization in the form of discussions, seminars, workshops, workshops, training, talks and simulations. KPUD Langkat Regency has not conducted face-to-face socialization properly in accordance with the regulation .The central KPU has also provided solutions for socialization methods by establishing Smart House Elections (RPP) as an alternative in an effort to increase voter participation. However, Langkat District Election Commission has not been able to form an RPP due to the condition of the KPU office which has not been possible to provide the space as the place of the RPP. Based on the above description, the authors are interested to take the title "The Role of Langkat Regency KPU In Order to Increase Voter Participation."

Based on the above description, the authors formulate problems in this study namely; 
1. How is KPU's role in improving electoral participation?

2. What does Langkat Regency PKU do in the election socialization?

3. How to socialize effective elections?

The purpose of this study is to determine the role of Regency Election Commission in order to increase voter participation.

Some benefits of this research are:

a. For related institutions expected to be used as learning to increase community participation of Langkat Regency.

b. Provide an opportunity for authors to further deepen the knowledge related to the role of Langkat Regency KPU in order to increase the participation of the election.

c. This study is expected to be useful and provide input for the interests and development of science and the results of this study can also be used as a reference in subsequent research.

\section{REVIEW OF LITERATURE}

\subsection{Election Socialization}

Socialization is a process of learning to a person to understand and have awareness of the role properly in the community. So socialization is also often said as the process of education to better know something that has not been known someone in social life, such as knowing the role, norms and values in the community to adapt and interact among human beings. According to Djuyandi (2014: 1204) socialization is generally understood as a learning process, this condition occurs because basically human nature is never going to be satisfied to learn something that is not yet known, such as learning about the role, norm and value to be able to adapt to the environment social. The socialization of elections is also included in the socialization of politics. In this case election socialization is a kind of formal socialization. According to Syarbaini (2014), the type of formal socialization, which is socialization conducted through authorized institutions according to state provisions or through institutions established under applicable laws and government 
regulations. Socialization conducted by government institutions, like the General Election Commission (KPU), is called formal socialization because the institution has authority and has legal basis, besides the material submitted by the institution is government policy. Type of formal socialization is a type that is often used by the government in socializing new programs or policies made to the public, such as the Election Commission in socializing the electoral process. Furthermore, in the regulation of KPU Number 5 Year 2015, the socialization of elections is called socialization of elections. Is the process of delivering information about the stages and programs of the election. It can be concluded that the socialization of elections is a process of delivering information about the stages and programs of elections conducted by the competent authorities established by law and the provisions applicable with the aim of providing awareness of the public about the importance of the election. The purpose of socialization of elections proposed by Djuyandi (2014: 1207) is to provide a good understanding to the community about the urgency of the election, so that the proactive attitude of the community to give their voting rights well, right and full of responsibility.

\subsection{Political Participation}

Arifin (2015: 77) says the involvement of individual citizens in political activity to various levels within the political system is called political participation. Political participation is also explained by Maran (2001: 147) as an organized effort by citizens to elect their leaders and influence the form and course of public policy. This effort is done based on the awareness of their responsibility to the common life as a nation within a country. According to Mc Closky in Budiardjo (1989: 1) says political participation is the process of electing the ruler, and directly or indirectly in the process of formation of public policy. Then Budiarjo (2008: 185) explains also about political participation is the activity of a person or group to participate actively in political life, among others by choosing the leader of the state and directly influence government policy. So political participation is the involvement of self, mental, thoughts and emotions or feelings of a person from various levels of political activity such as election activities of state leaders through elections as a form of awareness and responsibility of a person against government regulations or policies. The participation of the people in the general election is by participating 
in the implementation of the general election to achieve the goals of the nation and hasten in democracy.

\subsection{How to Increase Participation}

The way to increase participation by Nitisemito (1982: 262), is as follows: (a) to include them directly in the decision-making and planning process; (b) explain the purpose of the decision and the plan to be issued; (c) requesting feedback and suggestions on decisions and plans to be issued; (d) to request information about everything from them in making decisions and planning; (e) provide an opportunity to participate in shares; (f) increase delegation of authority. These are only a few ways to increase participation, because there are many other ways to increase participation that cannot be mentioned one by one because a proper way for an agency or company is not necessarily suitable for other agencies or companies.

\section{METHOD OF THE RESEARCH}

The type of research used is descriptive research type with qualitative data processing analysis that is problem-solving procedure that is investigated by observation by way of describing the state of the object of research at the present time, based on facts that appear or as it is. With reasons to know the fact that the variable has been running well or not. Based on the explanation Moleong (2012: 6) qualitative research is research that intends to understand the phenomenon of what is experienced by the subject of research such as behavior, perception, motivation, action, etc., holistically, and by way of description in the form of words and language, in a special context that is natural and by utilizing various natural methods. While the type of descriptive research is also put forward by Moleong (2012:11) is where the data collected are in the form of words, images, and not the numbers. Thus, the research report will contain excerpts derived from interview texts, field notes, and other official documents. In this research, data obtained from informants or informants are those directly related to the implementation of election socialization program in order to increase voter participation in Langkat Election Commission such as 2 people of KPU Kabupaten Langakat, 1 person of PPK (Sub-district 
Electoral Committee), 1 person PPS (Polling Committee), 1 person and 2 community leaders Langkat District.

\subsection{Technique of Collection Data}

The data collection technique is done by way that is; (1) primary data (through direct interviews with relevant sources) and; (2) secondary data (through print media, related documents and documentation).

\subsection{Technique of analysis Data}

The technique used is a qualitative data analysis technique that is by presenting data that begins by reviewing all available data from various collected resources, studying the data, reviewing it, compiling it in the units then categorized in the next step, and checking the validity of the data and interpreting it with analysis in accordance with the ability of the reasoning power of researchers to make research conclusions. The use of the method by considering that this research is trying to describe Langkat Regency KPU in order to increase participation And to draw conclusion based on the answer given by the resource person.

\section{DISCUSSION}

\subsection{The Role of KPU in the Framework of Increasing Voter Participation}

In order to increase voter participation of KPU (General Election Commission) both central, provincial, regency / municipality have an important role in it. In every series of KPU general election activities always have an agenda for welcoming the election event, among others; counseling, updating, technical guidance, socialization of election schedule, data collection to the preparation of election venue. These have been included in the framework of increasing voter participation in a single election period in both elections and elections. However, the main thing that has a direct influence on the level of voter participation is the election socialization process conducted by the KPU. Socialization is one of the programs in the series of election activities (election). Election socialization has become the responsibility of KPU in accordance with the explanation in Regulation of the General Election Commission Number 5 of 
2015 concerning Socialization and Public Participation in the Election of Governor and Deputy Governor, Regent and Deputy Regent and / or Mayor and Deputy Mayor. In article 1 point 10 explains that the Socialization of the Implementation of Elections, hereinafter referred to as Socialization of Elections. Socialization Elections is the process of delivering information about the stages and programs of the election. The purpose of the dissemination of elections by the KPU has been stipulated in the Regulation of KPU Number 5 Year 2015 article 3, namely: a) disseminating information on the stages, schedules and election program; b) enhancing community knowledge, understanding and awareness of the rights and obligations in elections; and c) increasing voter participation in elections. It is also mentioned in the regulation on the target of socialization of Article 4 election are:

a. Objectives in the implementation of Socialization of Elections, including components: a. general public; b. Beginner voters include youth, youth, students and students; c. community leaders and / or custom leaders; d. mass media groups; e. political parties; f. supervisors, Election Observers and Foreign Election Observers; g. community organization; h. religious organizations; i. indigenous groups; j. government agencies; k. political parties; and / or 1. Voters with special needs.

b. Voters with special needs as referred to in paragraph (1) letter 1 shall include persons with disabilities, people in border or remote areas, inmates, patients and hospital workers, offshore mining workers, plantations and other marginalized groups.

Article 9 of the regulation also mentions the method of socialization which may be carried out by the KPU through: (a) face-to-face communication; (b) the mass media; (c) socialization materials; (d) social mobilization; (e) utilization of local / traditional culture; (f) pages of Provincial KPU / KIP and / or Regency / Municipal KPU / KIP; (g) bulletin board of the Provincial KPK / KIP and / or Regency / Municipal KPU / KIP; (h) social media; (I) creative media; (J) another form that allows the public to be able to receive election information well. In accordance with the objective of socialization of elections, one of which has been mentioned above is to increase voter participation in the election. Therefore, socialization activities can increase voter participation. The success of socialization will determine the level of voter 
participation. Effective socialization will also encourage the level of voter participation at the expected level. Therefore, the need for effective socialization of elections. KPU of Langkat Regency In the Socialization of the General Election

The election socialization conducted by Langkat Regency Election have done:

a. Collaborate with KDP (Sub-district Election Committee) and PPS (Polling Committee) in the village / kelurahan and cooperate with capil in terms of provision of election requirements ie E-ID card considering based on Law Number 7 Year 2017 About the election which says the terms Absolute voters in elections are Electronic Identity Card (EID).

b. Establish billboards, banners, pamphlet, social media as a form of dissemination of information on general elections to the general public.

c. Socialization to high school schools, considering the age of senior high school is going to prospective voters beginner, so need to do the introduction of direct elections, as for the form of socialization conducted by conducting simulation of election through OSIS election guided by Langkat Regency KPU.

d. Arrangement of voter requirements. Record prospective voters in the village or sub-district.

e. Invites the community in socialization activities conducted by Langkat Regency KPU.

\subsection{Effectiveness of Election Socialization}

The socialization of the elections mentioned earlier is a program. In a program need socialization process or giving information and disseminate information about an activity, as well as election need to be disseminated to the public about the implementation of the election. The socialization of the election is also conducted in cooperation with elements supporting the success of political development, both community and other institutions / organizations. The effectiveness of a program is a condition that indicates the success rate of an activity. The effectiveness of election socialization is the success rate of the socialization program or the dissemination of information about elections, based on procedures and selection of objectives, through the use of resources, budget, facilities and infrastructure, and integration (socialization, consensus development and communication with various other organizations) organizational 
goals that have been consciously established beforehand.Based on the above description, the effectiveness of election socialization can also be measured its effectiveness. The effectiveness of electoral socialization can be said to be effective if assessing through these variables with views from; compliance of procedures, resource utilization, budgets, facilities and infrastructure, achievement of objectives and integration (socialization, consensus development and communication with various other organizations).

\section{CONCLUSION}

The conclusion of the role of Langkat Regency KPU in order to increase voter participation is done by socialization that can be measured the effectiveness of election socialization conducted. From the results of research conducted from several categorizations seen that:

a. Achievement of election socialization objectives at Langkat Regency Election Commission is less effective because voter participation is still standard. This is because there are still many people who do not have E-ID card as a condition of prospective voters. So the people who do not have these requirements are not listed in the temporary election list and cannot vote.

b. election socialization procedure is not effective because Langkat Regency KPU does not have a directed procedure as a corridor or guidelines for the implementation of election socialization properly and correctly.

c. Utilization of resources, with sufficient capacity and number of personnel in accordance with the number or needs of the districts . Langkat Regency has 23 Sub districts, each District has KDP and every village has its PPS. Each KDP has 5 officers including 1 chairman and 4 members. And each PPS has 3 officers including 1 chairman and 2 members.

d. The election socialization budget is still lacking because there are still socialization programs that are abolished due to insufficient budget. One of the disseminated socialization programs is the program of democracy volunteers. 
e. The existing facilities are adequate and support the implementation of election socialization. Utilization is effective in providing election information in accordance with the direction of Langkat Regency KPU. The facilities are banners, billboards and other socialization props spread throughout the villages.

f. Infrastructure has not been complete so it cannot be said to be effective in supporting the implementation of election socialization for example has not made a smart home election that can be used as an infrastructure for effective dissemination of elections.

g. The integration or cooperation made by Langkat Regency Election to organizations, agencies and other elements in the implementation of election socialization is not fully effective because the KPU does not cooperate with political parties in the process of disseminating the elections and the capil is also not effective because there are still many people who have not have E-ID cards so that the public can not be recorded in the election.

So based on the results of the research above shows that of the seven benchmarks of the effectiveness of election socialization there are 5 categorization that has not been effective and 2 effective categorization. Therefore it can be concluded that the election socialization conducted by Langkat Regency KPU in order to increase voter participation has not been effective.

\section{REFERENCES}

Arianto, Bismar. 2011. Analisis Penyebab Masyarakat Tidak Memilih Dalam Pemilu. E.Journal Ilmu Politik dan Ilmu Pemerintahan, Vol. 1, No. 1, 2011.

Arifin, Anwar. 2015. Perspektif Ilmu Politik. Jakarta: Pustaka Indonesia.

Budiardjo, Miriam. 2008. Dasar-Dasar Ilmu Politik. Jakarta: Gramedia Pustaka Utama.

Djuyandi, Yusa. 2014. Efektivitas Sosialisasi Politik Pemilihan Umum Legislatif Tahun 2014 Oleh Komisi Pemilihan Umum. E.Journal HUMANIORA, Vol.5, No.2 Oktober 2014: 1202-1212.

Maran, 2001. Pengantar Sosiologi Politik. Jakarta: Rineka Cipta. 
Moleong, L. 2012. Metodologi Penelitian Kualitatif. Bandung: PT. Remaja Rosdakarya.

Nitisemito, S. Alex. 1982. Menejemen Personalia (MSDM). Jakarta: Ghalia Indonesia.

Constitution

Law Number 22 Year 2007 regarding the holding of general elections.

KPU Regulation No. 5 of 2015 on Socialization and Public Participation 